\title{
A preliminary study on nutrient digestibility by West African dwarf goats fed graded levels of shea nut (Vitellaria paradoxa) cake-based rations
}

Ogunbosoye D. O.?, Tona, G. O. ${ }^{2}$, Akinfemi, A. ${ }^{3}$ and Ajani, M. R. ${ }^{4}$

${ }^{1,4}$ Department of Animal Production, Fisheries and Aquaculture, Kwara State University, Malete, Nigeria

${ }^{2} 1$ Department of Animal Production and Health, Ladoke Akintola University of

Technology, Ogbomoso. Nigeria

${ }^{3}$ Department of Agric. Technology, Yaba College of Technology, P.M.B 2011, Yaba Lagos, Nigeria

*Corresponding E-mail: olufunflory@ymail.com

\section{Abstract}

Feed shortage which rises from seasonal feed deficits, erratic supply of feed ingredients with competition between humans and livestock for available feed resources, possesses a major constraint to goat production in Nigeria. This has led to low level of livestock productivity. In this regards, there is need to search for alternative but cheaper feedstuffs. Shea nut cake $(S N C)$, an agro industrial waste product could be used as one of the economic strategy to ameliorate feed shortage. The current study was focused on the effect of dietary inclusion of Shea nut cake on nutrients digestibility of West African Dwarf goats using six (6) growing males WAD goats. Diets consist of $0 \%, 10 \%$ and $15 \%$ shea nut cake inclusion levels in combination with wheat offal, corn bran, cassava peel, cowpea husk, and the dietary treatments were designated as T1, T2, and T3 respectively. The experimental animals were allotted to three treatments in a completely randomized design with two animals per treatment. The animals were transferred into a wooden metabolic cage fitted with facilities to collect faeces which lasted for 14 days. Crude protein, ether extract, ash and neutral detergent fibre concentrations of the experimental diets were 9.18-11.37\%, 2.03-2.79, 9.63$12.11 \%$ and $30.69-48.51 \%$ respectively. The result obtained for average daily weight gain was higher $(p<0.05)$ for T2 (64.29g) compared to T1 (35.72g) and T3 (35.72g) which were similar. The feed conversion ratio showed no significant $(p<0.05)$ effect among T1 (14.32) and T3 (14.07) while T2 (8.00) is significantly higher. Significant differences $(p<0.05)$ were observed among treatment groups for nutrients digestibility. The goats placed under T2 (10\%) recorded the highest digestibility coefficient for all the nutrients. However the crude protein, ether extract, ash and neutral detergent fibre digestibilities were between 45.76$74.26 \%, 57.19-67.73 \%, 56.09-76.66 \%$ and $55.28-78.28 \%$ respectively. It was however observed that T2 (10\%) SNC inclusion had the highest digestibility coefficient in all the nutrients by West African dwarfgoats.

Keywords: Agro -industrial waste, digestibility, feed deficits and shea nut cake

\section{Introduction}

Feed shortage possesses a major constraint to goat production in Nigeria (Belewu et al., 2007, Ahamefule and Elendu, 2010). Even where fodder resources abound, seasonal fluctuations in nutritive value make sustainable gain in production from good management and disease control program unrealistic (Alli-Balogun et al., 2003). This is aggravated by seasonal fluctuation that affects the nutritive quality of native pasture most especially during the dry season and the steady increase in prices of feed ingredients due to competition between man and livestock. Ruminants in the tropics in general, are raised predominantly on 
grasses which are inherently poor in digestibility, nutritive value and unavailability in off season (Babayemi et al., 2009). At this period, the performance of the ruminant animals which is dependent on this native pasture is seriously impaired coupled with the fibrous and lignified nature of the pasture which limits intake, digestibility and utilization. Meanwhile, during this critical period, the production level of the animal is low and consequently resulted to the low income accruable from these animals. Some of the animals are lost through premature disposal or death in some cases.

This shortage of good quality feeds needed to sustain ruminant livestock growth, especially during the dry season has been a major challenge to the small ruminant subsector in the Nigeria agricultural economy (Ososanya et al., 2013). Therefore, a feeding strategy needs to be developed in tropical countries that will gear towards searching for inexpensive readily available feed resources. This problem has stimulated this search for cheaper alternative feed resources that can economically supplement feed ingredients in rations without adverse effects on the health, digestibility, nutrient intake and performance of small ruminant animals (sheep and goats). Indeed, there is the need to sustain supplementation by exploring cheaper sources for supplementary feed because agro-industrial by-products stand a greater chance of effective and efficient utilization at this period because of its availability and storability. Agro-industrial by-products such as maize bran (MB), rice bran (RB) and wheat offal (WO) have been used to form different rations for livestock especially ruminant. However, much work has been done with the use of crop residues and some agro industrial by-products as supplementary feed for goats in particular and ruminants in general. Gibson (2007) stated that goats are inquisitive feeders with high efficiency in energy and protein conversion from feeds. The ability of the goats therefore, to eat feed stuff and digest cellulose which are not normally eaten or accessible to other animals enhance their overall competitive efficiency.

Shea nut cake (SNC) is one of the agroindustrial by-products produced in the processing of shea nut into shea butter (Asante, 1987). The shea nut tree (Vitellaria paradoxa) occurs predominantly in the northern, upper east and upper west regions of Ghana and some parts of Nigeria (FAO, 1988). The tree is perennial and deciduous and occurs mainly on dry open slopes (Yidana, 2004). The Shea tree attains height of about $6.1 \mathrm{~m}$ and girths of $61 \mathrm{~cm}$ in the wild when it is often ravaged by bushfires. They can however reach heights of about $15 \mathrm{~m}$ and $17 \mathrm{~cm}$ girths under protected conditions. The trees grow slowly from seeds, taking about 30 years to maturity. One of the key agro-forestry species in Africa, particularly Nigeria is the shea butter tree, Vitellaria paradoxa syn. Butyrospermum paradoxum (Sapotaceae). The shea tree produces fruits which is cherished and eaten by humans and animals; the nut of this fruit is processed to give shea butter, while the residue or by product is the shea nut cake (Dei et al., 2008). Approximately 500,000MT of this cake are produced annually in the savannah region of West Africa (Okai and Bonsi, 1989). The shea nut cake (SNC) is an end product; available in large quantity and generally disposed of via incineration, because it is considered useless, causes hazard to the environment and pollution. SNC have been reported to contain anti nutritional factors such as theobromine, saponin and tannin which at certain levels lower feed intake, digestibility and 
Ogunbosoye, Tona, Akinfemi and Ajani

absorption in non-ruminants (Morgan et al., 1980; Okai and Bonsi, 1989; Atuahene., et al 1998). Some works have been done on the use of SNC as feed for supplementing sheep. These include; the preference study of varying level of SNC utilization by sheep (Esien, 2003) and the growth response of goats and sheep fed SNC-based diet (Issaka, 2006).

Digestibility is simply a measure of the availability of nutrients. However, digestibility usually provides a fairly reliable index of nutritive value because more digestible feeds are normally consumed to a greater extent than less digestible feeds. In addition, measures of digestibility are somewhat easier to obtain than measures of intake. Hence the focus of this study is to assess the potential utilization of shea nut cake at graded levels of inclusion through digestibility study by
West African dwarf goats.

\section{Materials and methods Experimental site}

The experiment was conducted at the goat section of the Teaching and Research Farm, Kwara State University Malete located in Guinea Savannah region of Nigeria. The state experiences rainy and dry seasons. The mean minimum temperature range of the State is $24-32^{\circ} \mathrm{C}$ while the mean maximum range is $35-38^{\circ} \mathrm{C}$. The latitude of the study area is 8.7 and longitude is 4.5 .

\section{Experimental diet}

Shea nut was sourced from a local Shea butter processing factory in Ilorin. It was sun dried for four days, ground with mortar and pestle before sieving with $4.0 \mathrm{~mm}$ mesh sieve to fine particles and weighed before mixing with other feed ingredients (Wheat offal, corn bran, cowpea husks, and cassava peels).

Table 1: Composition of experimental diets (kgDM)

\begin{tabular}{llll}
\hline Ingredients & T1 (0\%) & T2 (10\%) & T3 (15\%) \\
\hline Cassava peel & 25 & 22.5 & 21.25 \\
Wheat offal & 25 & 22.5 & 21.25 \\
Cowpea husk & 25 & 22.5 & 21.25 \\
Corn bran & 25 & 22.5 & 21.25 \\
Shea nut cake (SNC) & - & 10.0 & 15.0 \\
Total & 100 & 100 & 100 \\
\hline
\end{tabular}

\section{Experimental design and digestibility}

Two animals per treatment were transferred into a wooden metabolic cage fitted with facilities to collect faeces in a completely randomized design. The study lasted for 14 days which include 7 days for adjustment period and 7 days for collection during which the animals grouped into treatments were fed total mixed rations containing Shea nut cake at graded levels of 0,10 , and $15 \%$. Feed was offered daily at 08:00 and water provided ad-libitum. During the experimental period, the quantity of feed offered, feed refusal, faeces were recorded.

\section{Collection of Faeces}

After 7 days of adjustment period, total collection of daily faeces from individual animals was collected and weighed daily for 7 days, then $10 \%$ of the daily collection was collected for oven drying at $100-105^{\circ} \mathrm{c}$ for $48 \mathrm{hrs}$. The dried faeces collected were bulked and milled through $2 \mathrm{~mm}$ screen sieve and stored in well-labelled air tight bottles for chemical analysis.

\section{Chemical analysis}

Samples of feeds and faeces were oven dried at $70^{\circ} \mathrm{C}$ for $48 \mathrm{hrs}$ and ground in a hammer mill to pass a $1 \mathrm{~mm}$ mesh sieve and 
stored for chemical analysis. Nitrogen content of the feed, faeces was determined by the micro-kjeldahl technique using the Markham's distillation apparatus. These samples were analysed for crude protein, crude fibre, ether extract, and ash by AOAC, (2005). Neutral detergent fibre, acid detergent fibre and acid detergent lignin were determined according to the methods of Van Soest et al. (1991). Results obtained were used for the calculation of nutrients digestibility of the experimental animals.

\section{Statistical Analysis}

The data obtained were subjected to oneway analysis of variance (ANOVA) in a Completely randomized Design (CRD) using SAS package (2010) and where significant difference between the means exist, Duncan multiple range test (DMRT) was used to separate the means.

\section{Results and discussion}

Presented in Table 2 is the chemical composition of the experimental diets. The chemical composition of experimental diets containing varying inclusion levels of shea nut cake differed $(\mathrm{p}<0.05)$ significantly among the diets. The Crude protein content of diet reduced with the increasing level of SNC having highest $(11.37 \%)$ value in $\mathrm{T} 1$ and lowest in T3 (9.18\%). However, the crude protein values recorded for diets were within the $9-12 \%$ crude protein for moderate level required by ruminants for minimum growth performance (Gatemby, 2002). The high crude protein contents of the diets show that the feed will be able to meet the optimum microbial need in the rumen. Crude fibre content of diet T3 (19.54\%) was significantly higher than in T1 (17.20\%) and T2 (16.84\%). High level of crude fibre could inhibit digestibility. Baiden et al., (2007) reported that microbial colonization of low fibre feed is more than that of higher fibre content. T2 was significantly different compared to other treatment in ether extract. The low concentration of ether extract in the experimental diets is an indication that the meat produced from the animals fed the diets will contain less fat. The ash content obtained in this present study was higher than what was reported elsewhere (Ajayi et al., 2009). There were significant differences $(\mathrm{p}<0.05)$ in the fibre fractions. Neutral detergent fibre, Acid detergent fibre and Acid detergent lignin of the diets ranged between $(30.69-48.51 \%)$, (21.56 $41.17 \%)$ and $(8.96-12.53 \%)$ respectively. The fibre fraction concentrations were within the values reported when corn cob was included in the ration of N'dama cattle (Ajayi et al., 2009).

Table 2: Chemical composition of experimental diets (\%)

\begin{tabular}{lllll}
\hline Nutrients & T1 $(\mathbf{0 \%})$ & T2 $(\mathbf{1 0 \%})$ & T3 (15\%) & SEM \\
\hline DM & $92.42^{\mathrm{b}}$ & $93.03^{\mathrm{a}}$ & $92.90^{\mathrm{ab}}$ & 0.14 \\
CP & $11.37^{\mathrm{a}}$ & $9.84^{\mathrm{b}}$ & $9.18^{\mathrm{b}}$ & 0.33 \\
EE & $2.03^{\mathrm{b}}$ & $2.79^{\mathrm{a}}$ & $2.19^{\mathrm{b}}$ & 0.09 \\
CF & $17.20^{\mathrm{b}}$ & $16.84^{\mathrm{b}}$ & $19.54^{\mathrm{a}}$ & 0.20 \\
ASH & $9.63^{\mathrm{b}}$ & $11.24^{\mathrm{ab}}$ & $12.11^{\mathrm{a}}$ & 0.54 \\
NDF & $30.69^{\mathrm{b}}$ & $48.15^{\mathrm{ab}}$ & $40.40^{\mathrm{a}}$ & 0.33 \\
ADF & $21.56^{\mathrm{c}}$ & $41.17^{\mathrm{a}}$ & $32.35^{\mathrm{b}}$ & 0.34 \\
ADL & $12.35^{\mathrm{a}}$ & $8.96^{\mathrm{b}}$ & $9.73^{\mathrm{b}}$ & 0.47 \\
\hline
\end{tabular}

$\mathrm{abc}=$ The means within same row with different superscript are significantly different $(\mathrm{P}<0.05)$ 


\section{Ogunbosoye, Tona, Akinfemi and Ajani}

Presented in Table 3 are the Daily weight gain, daily feed intake and feed conversion ratio of WAD goats fed experimental diets. Values for daily weight gained were similar in animals on diets T3 (35.72g) and T1 (35.72g) but animals on diet T2 (64.29g) had the highest weight gained. There were significant different in daily feed intake where T2 $(571.95 \mathrm{~g})$ is significantly higher than T1 (491.75g) and T3 (487.10g). The animals under T2 consumed more feed on daily basis than other animals on $\mathrm{T} 1$ and T3.. However, the highest feed intake value obtained on diet 2 might be as a result of palatability and the nature of diet preparation. Morgan and Lewis, (1961), stated that the voluntary feed intake of any animals is a primary determinant of the nutrient digestibility and productivity. McDonalds et al., (1995) reported that nutrient intake is the most important factor that affects animal performance. FCR also followed the same pattern. It revealed the ability of animals on T2 (8.00) to consume more feed but utilized and converted the feed to more flesh than animals in $\mathrm{T} 1$ (14.32) and T3 (14.09).

Table 3: Daily weight gain, daily feed intake and feed conversion ratio of WAD goats fed experimental diets

\begin{tabular}{lllll}
\hline Parameters & T1 (0\%) & T2 10\%) & T3 (15\%) & SEM \\
\hline IW $(\mathrm{kg})$ & 11.50 & 13.75 & 12.60 & \\
FW $(\mathrm{kg})$ & $11.75^{\mathrm{c}}$ & $14.20^{\mathrm{a}}$ & $12.85^{\mathrm{b}}$ & 0.18 \\
DWG $(\mathrm{g})$ & $35.72^{\mathrm{b}}$ & $64.29^{\mathrm{a}}$ & $35.72^{\mathrm{b}}$ & 8.25 \\
DFI $(\mathrm{g})$ & $491.75^{\mathrm{b}}$ & $571.95^{\mathrm{a}}$ & $487.10^{\mathrm{b}}$ & 5.94 \\
DFIg/dW & 20.75 & 19.34 & 18.12 & 0.44 \\
FCR & $14.32^{\mathrm{b}}$ & $8.00^{\mathrm{a}}$ & $14.09^{\mathrm{b}}$ & 2.82 \\
\hline
\end{tabular}

$\mathrm{abc}=$ The means within same row with different superscript are significantly different $(\mathrm{P}<0.05) . \mathrm{IW}=$ Initial weight, $\mathrm{FW}=$ final weight, $\mathrm{DWG}=$ daily weight gain, $\mathrm{DFI}=$ daily feed intake, $\mathrm{DMS}=$ daily metabolic size and $\mathrm{FCR}=$ feed conversion ratio.

Apparent digestibility of the various nutrients is presented in Table 4. The dry matter digestibility values obtained were not significantly $(\mathrm{p}>0.05)$ difference among T2 $(82.86 \%)$ and T1 $(80.37 \%)$ but significantly higher than of T3 $(66.88 \%)$. DM intake is an important factor in the utilization of feed by ruminants and is a critical determinant of energy and performance in small ruminants (Devant et al., 2000). Treatment $\mathrm{T} 2$ had the highest dry matter digestibility suggesting a more effective utilization of that feed. Digestion in the rumen is dependent on the activity of micro-organisms. It also requires energy, nitrogen, minerals and a suitable medium to enable the microbes perform well (Ranjhan, 2001). Gutteridge and Shelton, (1998) reported that dry matter digestibility characteristics may be due to the wall configuration of their polysaccharides and their effect on microbial attachments and colonization of digest particles. Crude protein, digestibility was highest in goats fed diet T2 $(74.26 \%)$ and lowest in goats fed diet T3 (45.76\%). Animals on T2 (74.26\%) digested more crude protein than those on T1 $(73.88 \%)$ and T3 (45.76\%). Indeed animals fed with diet T3 had abysmally low protein digestibility. The digestibility values for goats on diet T2 and T1 were similar ( $p>0.05)$ in CF. The CP digestibility obtained in this present study was lower than what was reported elsewhere (Bello and Tsado, 2013). Crude fibre digestibility was fairly good. Animals on T3 recorded the lowest rumen crude fibre degradation compared to those on $\mathrm{T} 2$ and $\mathrm{T} 1$. Ether 
extract digestibility in T1 was significantly higher than T2 and T3 which has the lowest ether extract digestibility. There were significant differences $(\mathrm{p}<0.05)$ in all treatments for mineral (ash) digestibility and was very high in $\mathrm{T} 2$ and $\mathrm{T} 1$ with $\mathrm{T} 3$ recording the lowest amongst the treatments. The values obtained were comparable to reported values (Ososanya et.al. 2013) for WAD sheep fed diet mixtures comprising dried cassava peel, wheat offal and palm kernel oil. These observed differences in ether extract and ash digestibilities could probably be a true reflection of the component of the diets since nutrient digestibility, among other factors could depend on the proximate composition of a ration. Many other factors, including particle size, chewing frequency and effectiveness, particle fragility, indigestible fraction, rate of fermentation of the characteristics of reticular contraction are also involved. NDF digestibility values were not significantly different $(p>0.05)$ between $\mathrm{T} 1$ and $\mathrm{T} 3$ where $\mathrm{T} 2$ has the highest NDF digestibility compared to other treatments. Similar trend was observed in ADF digestibility. There were no significant $(p<0.05)$ differences in ADF digestibility of animals in diets $\mathrm{T} 1 \quad(64.64 \%)$ and $\mathrm{T} 3$ $(56.52 \%)$ but significantly higher in animals on T2 $(79.96 \%)$. The value obtained in this study was in agreement with the range (63.3-78.4\%) obtained by Olorunnisomo and Ososanya, (2002) who fed maize offal and sorghum brewers grain as supplement to WAD goats. Generally, animals on T2 $(10 \%)$ digested more of the nutrients in the diets offered to them than those in T1, the control diet and T3. Hence, study on nutrient digestibility is said to be important as it allows the estimation of nutrient actually available for animal performance (Okoruwa and Adewumi, 2010).

Table 4: Apparent nutrient digestibility coefficient (\%) of WAD goats fed graded level of shea nut cake

\begin{tabular}{lllll}
\hline $\begin{array}{l}\text { Nutrient } \\
\text { digestibility (\%) }\end{array}$ & T1 (0) & T2 (10\%) & T1 (15\%) & SEM \\
\hline DM & $80.37^{\mathrm{a}}$ & $82.86^{\mathrm{a}}$ & $66.88^{\mathrm{b}}$ & 1.27 \\
CP & $73.88^{\mathrm{a}}$ & $74.26^{\mathrm{a}}$ & $45.76^{\mathrm{b}}$ & 3.65 \\
EE & $67.73^{\mathrm{a}}$ & $62.53^{\mathrm{b}}$ & $17.19^{\mathrm{c}}$ & 0.13 \\
CF & $74.12^{\mathrm{a}}$ & $75.32^{\mathrm{a}}$ & $56.01^{\mathrm{b}}$ & 1.60 \\
ASH & $67.51^{\mathrm{b}}$ & $76.66^{\mathrm{a}}$ & $56.09^{\mathrm{c}}$ & 1.19 \\
NDF & $66.42^{\mathrm{b}}$ & $78.28^{\mathrm{a}}$ & $55.28^{\mathrm{b}}$ & 1.86 \\
ADF & $64.64^{\mathrm{b}}$ & $79.96^{\mathrm{a}}$ & $56.52^{\mathrm{b}}$ & 1.68 \\
ADL & $85.36^{\mathrm{a}}$ & $85.65^{\mathrm{a}}$ & $73.84^{\mathrm{b}}$ & 1.03 \\
\hline
\end{tabular}

a,b,c, = Treatment means on the same row with different superscript differ significantly $(\mathrm{P}<0.05)$

From the results obtained in this research work, it could be concluded that shea nut cake could be best utilized by West African dwarf goats at $10 \%$ inclusion to mitigate feed shortage during lean period. It is therefore recommended that shea nut cake should be incorporated in the diet of WAD goats at $10 \%$ level inclusion. The authors hereby suggest that further research should be carried out using shea nut cake at higher levels of inclusion in the diets to verify its further utilization by the animals.

\section{References}

Ahamefule, F. O. and Elendu, C. 2010. Intake and digestibility of West African Dwarf bucks fed cassava leaf-maize offal based diets. Journal of Animal Veterinary Advances., 9: 535-539. 


\section{Ogunbosoye, Tona, Akinfemi and Ajani}

Ajayi, F. T., Babayemi, O. J., and Taiwo A. A. 2009. Mineral solubility of panicum maximum with four forage legume mixtures incubated in the rumen of N'dama steers. Animal science Journal 80:250257

Alli-Balogun, J. K., Lakpini, C. A. M., Alawa, J. P., Mohammed, A. and Nwanta, J. A. 2003. Evaluation of cassava foliage as a protein supplement for sheep. Nigerian Journal of Animal Production, 30: 37-46.

Asante, F. 1987. Preliminary study of the value of shea nut cake as a feed ingredient of broiler finisher diet. B.Sc. Agric. Dissertation, U.S.T., Kumasi, pp 24-28.

Association of Official Analytical Chemist AOAC. 2005. Official Method of Analysis $15^{\text {th }}$ edition. Washington. D.C. U.S.A Pg 6990.

Atuahene, C. C., Donkoh, A. and Asante, F. 1998. Value of sheanut cake as a dietary ingredient for broiler chickens. Animal Feed Science and Technology, 72: 133-142.

Babayemi, O. J., Ekokotu, O. A. and Iyayi, E. A. 2009. Evaluation of ensiled cassava peels together with Albizia samam pods in: Animal Agriculture and the global food challenges. Proc. 34th Annual Conference Nigeria Society of Animal Production, University of Uyo, Uyo, Nigeria. Pp.514-517.

Baiden, R. Y., Rhule, S. W. A., Otsyina, H. R., Sottie, E. T. and Ameleke, G. 2007. Performance of West African Dwarf sheep and goats fed varying levels of cassava pulp as a replacement for cassava peels. Livestock Research for Rural Development. Volume 19, Article
\#35 Retrieved October 30, 2013

Belewu, M. A., Orisameyiti, B. R. and Ajibola, K. A. 2007. Effect of feeding graded levels of tiger nut (Cyperus esculentus) seed meal on the performance characteristics of West African dwarf goat. Pakistan Journal of Nutrition, 6: 528-529

Bello, A. A. and Tsado, D. N. 2013. Feed Intake and Nutrient Digestibility of Growing Yankasa Rams Fed Sorghum Stover Supplemented with Graded Levels of Dried Poultry Droppings Based Diet. Asian Journal of Animal Sciences, 7: 56-63.

Dei, H. K., Rose, S. P. and Mackenzie, A. M. 2008. Metabolisable energy in different shea nut (Vitellaria paradoxa) meal samples for broiler chickens. Poultry Science 87:694-699.

Devant, M., A. Ferret, S., Calsamiglia, and Casal, R. 2000. Effect of protein concentration and degradability on performance, ruminal fermentation and nitrogen metabolism in rapidly growing heifers fed high concentrate diets from $100-230 \mathrm{~kg}$ body weight. Journal of Animal Science, 78: 1667-1676.

Esien, J. 2003. Preference study of varying levels of shea nut cake with wheat or rice bran on sheep. BSc. (Agric. Tech) Dissertation, University for Development Studies, Tamale, 825.

Food and Agriculture Organization 1988. Traditional food plants. Food and Nutrition Paper. 42: 1593.

Gatemby, R. M. 2002. Sheep revised edition. Tropical Agricultural Series. Macmillan Publishers Ltd. Pp. 8-9 
Nutrient digestibility by West African dwarf goats fed graded levels of shea nut (Vitellaria paradoxa) cake-based rations

Gibson, A. T. 2007. Meet goat breeds and breeding plans. Agricultural Research Services United States Department of Agriculture. (http://aq.goat world.com $/ \mathrm{htm}$ ) $17 / 8 / 2007$.

Gutteridge, R. C. and Shelton, H. M. 1998. Forage tree legumes in tropical agriculture. CAB International, Wallingford, UK,

Issaka, J. 2006. Studies on nutritive value of sheanut cake, further studies on the growth response of sheep fed sheanut cake-based diets. BSc. (Agric. Tech) Dissertation, University for Development Studies, Tamale, Ghana pp 20-26

McDonald, P., Edwards, R. H. and Greenhalgh, J. F. D. 1995. Animal Nutrition, 5th edition. Longman Publishers Ltd., Singapore, pp. 583-585

Morgan, D. E. and Trinder, H. 1980. The composition of nutritional byproducts of ruminants. ADAS Regional Nutrition, Chemistry Department, Wolver Hampton, New castle-Upon-Tyne, pp 101108.

Morgan, J. T. and Lewis, D. 1961. Nutrition of pigs and poultry. William Clowes and Son Limited, London.

Okai, D. B. and Bonsi, M. L. K. 1989. Sheanut cake as a substitute for maize in the diet of Growing gilts. Kwame Nkuumah University of Science and Technology Ghana. 9: 45-50.

Okoruwa, M. I. And Adewumi, M. K. 2010. Effect of replacing Panicum maximum with dried pineapple pulp on nutrient digestibility and nitrogen balance of West African dwarf sheep. Nigeria Journal of
Animal Science. 2010; 32: 108-115.

Olafadehan, O. A., Olafadehan, O. O., Obun, C. O., Yusuf, A. M., Adeniji, A. A., Olayinka, O. O. and Abudulahi, B. 2009. Intake and digestibility of Red Sokoto Goats fed varying proportion of Andropogongayanus and Pterocarpuserinaceus forage, Proc. 14th Annual Conference Animal Science Association Nigeria. LadokeAkintola University of Technology, Ogbomoso, and Nigeria.Pp.572574.

Ososanya, T. O., Alabi, B. O. and Sorunke, A. O. 2013. Performance and digestibility of corncob and cowpea husk diets by West African dwarf sheep. Pakistan Journal Nutrition, 2013;12 (1): 85-88.

Ranjhan, S. K. 2001. Animal nutrition in the tropics, $5^{\text {th }}$ Edition., Vikas publishing house PVT Ltd, New Delhi, India, pp: 556-559.

SAS. 2010. The Statistical Analysis System for windows. SAS software, version 9.0 cary NC USA.

Van Soest, P. J., Robertson, J. B. and Lewis, B. 1991. Methods for dietary fiber, and non starch polysaccharides in relation to animal nutrition, J. Dairy Sci. 74, 3587-3597.

Yidana, J. A. 2004. Progress in Developing Technologies to Domesticate the Cultivation of Shea Tree (Vitellaria paradoxa L) in Ghana. Agricultural and Food Science Journal of Ghana 3: 249.

Received: $3^{\text {rd }}$ September, 2016 Accepted: $19^{\text {th }}$ January, 2017 